\title{
A MULTICRITERIA MODEL TO ASSESS TRACTORS USED IN FAMILY AGRICULTURE ${ }^{1}$
}

\author{
ÂNGELO V. DOS REIS ${ }^{2}$, ANTÔNIO L. T. MACHADO ${ }^{3}$, MÁRIO C. GOMES ${ }^{4}$, \\ NORBERTO L. M. ANDERSSON ${ }^{5}$, ROBERTO L. T. MACHADO ${ }^{6}$
}

\begin{abstract}
In recent years, public policy has been offering subsidized credit for machine purchase to family farmers. However, there is no methodological procedure to select a suitable tractor for these farmers' situation. In this way, we aimed to develop a selection model for smallholder farmers from Pelotas city region in the state of Rio Grande do Sul. Building a multicriteria model to aid decisions is divided into three main stages: structuring stage (identifying stakeholders, decisional context and model creation), evaluation stage (stakeholder preference quantification) and recommendation stage (choice selection). The Multicriteria method is able to identify and value the criteria used in tractor selection by regional family farmers. Six main evaluation areas were identified: operational cost (weight 0.20), purchase cost (weight 0.22), maintainability (weight 0.10 ), tractor capacity (weight 0.26 ), ergonomics (weight 0.14 ) and safety (weight 0.08$)$. The best-rated tractor model $(14.7 \mathrm{~kW}$ rated power) also was the one purchased by $53.3 \%$ of local families.
\end{abstract}

KEY-WORDS: machine selection; small farms; MCDA; PRONAF

\section{UM MODELO MULTICRITÉRIO PARA A AVALIAÇÃO DE TRATORES PARA A AGRICULTURA FAMILIAR ${ }^{1}$}

RESUMO: Nos últimos anos, as políticas públicas vêm disponibilizando aos agricultores familiares crédito subsidiado para aquisição de máquinas agrícolas. No entanto, não há uma sistemática que possa ser utilizada para a seleção dos tratores mais adequados à realidade dos agricultores. Sendo assim, o objetivo deste trabalho é propor um modelo para a seleção de tratores destinados a agricultores de base familiar em municípios da região de Pelotas, Rio Grande do Sul. Para a construção do modelo, foi empregada a Metodologia Multicritério em Apoio à Decisão, que está dividida em três fases principais: a fase de estruturação (identificação de atores, contexto decisional e criação do modelo), a fase de avaliação (quantificação das preferências dos atores) e a fase de recomendações (seleção das melhores opções). O uso da metodologia multicritério permitiu identificar e valorar os critérios empregados na escolha de tratores por parte dos agricultores familiares desta região. Foram identificados seis eixos principais de avaliação: custo operacional (peso 0,20), custo de aquisição (peso 0,22), facilidade de manutenção (peso 0,10), capacidade do trator (peso 0,26 ), ergonomia (peso 0,14 ) e segurança (peso 0,08 ). O trator mais bem pontuado no modelo (14,7 kW de potência nominal) também foi aquele adquirido por 53,3\% das famílias.

PALAVRAS-CHAVE: seleção de máquinas; pequenas propriedades; MCDA; PRONAF.

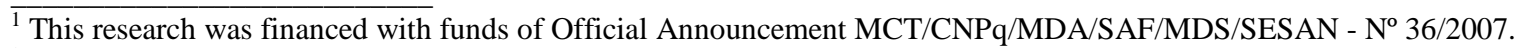

${ }^{2}$ Eng $^{\circ}$ Agrícola, Prof. Doutor, Departamento de Engenharia Rural, UFPel/Pelotas - RS, Fone: (53) 3275-7126, areis@ufpel.edu.br Pesquisador do CNPq

${ }^{3}$ Eng $^{\circ}$ Agrícola, Prof. Doutor, Departamento de Engenharia Rural, UFPel/Pelotas - RS, lilles@ufpel.edu.br - Pesquisador do CNPq

${ }^{4}$ Eng ${ }^{\circ}$ Agrônomo, Prof. Doutor, Departamento de Ciências Sociais e Agrárias, UFPel/Pelotas - RS, mcgomes@ufpel.edu.br

${ }^{5}$ Eng ${ }^{\circ}$ Agrícola, Eng ${ }^{\circ}$ Agrônomo, Doutorando, Programa de Pós-Graduação em Sistemas de Produção Agrícola Familiar,

UFPel/Pelotas - RS, norbertoan@ibest.com.br

${ }^{6}$ Eng $^{\circ}$ Agrícola, Prof. Doutor, Departamento de Engenharia Rural, UFPel/Pelotas - RS, rlilles@ufpel.edu.br - Pesquisador do CNPq Recebido pelo Conselho Editorial em: 19-12-2011

Aprovado pelo Conselho Editorial em: 8-2-2014
} 


\section{INTRODUCTION}

According to GUILHOTO et al. (2007), wealth generation by family farming productive chain represented 10\% of Brazilian GDP between 1995 and 2005, which has corresponded to almost one third of total farming productive chain at the same period.

In recent years, public policy has started to realize the importance of smallholder agriculture mainly under credit programs as the National Program of Sustainable Family Agriculture (PRONAF) of More Food Program (Programa Mais Alimentos) line.

ANDERSSON et al. (2009), studying family farmers that have received PRONAF resources, observed that this program has been determinant to tractor acquisition. This is observed at a national level, since the More Food Program alone accounted for more than 11,000 subsidized small tractor purchases in the first ten months of the program (MAWAKDIYE, 2010).

Owning their own tractor has always been an aspiration of major family farmers. However, purchasing one is almost impossible, since payment terms and financing conditions are the same for both small and high powered tractors. Conditions offered by the More Food Program changed this scenario: individual credit may be paid back in up to ten years with a three-year exemption $2 \%$ annual interest rate (MDA, 2011). Such an amount shall allow a $55 \mathrm{~kW}$ tractor purchase within the More Food line of the PRONAF Program.

According to data of ANFAVEA (2011), in the year 2010, Brazil manufactured 44,071 tractors of 37 to $55 \mathrm{~kW}$, whereas in 2000 the amount was a mere 14,678 tractors. This fact becomes an indicative of the credit program's importance by the Federal Government to smallholder farmers.

According to MACHADO et al. (2010), Family Agriculture is integrating a new reality: the use of intensive means of production through agricultural mechanization of family production units which, although desirable, brings along environmental and economic risks. These authors point out that machines are being purchased with little to no technical criterion due to the absence of systematic selection, which considers the relevant aspects of the machine related to the farmer productive system.

The importance of ideal machine selection is highlighted by AYBEK \& BOZ (2006). According to these authors, farmers need to take care of machine purchasing and usage, as they cost $50 \%$ of total agricultural production during field operations. It is also stated by these same authors that the proper selection of equipment is fundamental and might directly influence in the economical sustainability of farms.

MEHTA et al. (2011), considering the Indian agriculture where smallholders are prevalent, affirmed that tractor selection and ideal implement choice are becoming increasingly difficult over time; among quoted reasons is the great number of currently available tractor models. Authors emphasize that the tractors' technical performance at certain tasks is the main aspect taken into account for selection.

Nevertheless, the multiplicity of criteria suggested for an adequate tractor selection (MACHADO et al., 2010) is observed in most available models, among them the MEHTA et al. (2011) and SØGAARD \& SØRENSEN (2004) which are based on economic (total cost minimization) and/or technical (force or power drawbar) criteria.

Thus, the central subject of this research is an evaluation of adequate tractor selection to family agriculture. The diversity of criteria turns the problem into something more complex than expected and might come in conflict with each other; conflict resolutions, however, are generally linked to the attribution of weights to each criterion. An appropriate response to this matter goes through the constructivist work paradigm that covers the values of the people with the most interest in purchase decision and a method choice that covers their concerns in this kind of decision. 
Considering the subject's complexity, which is tractor selection for smallholder farmers, the purpose of this paper is to suggest a tractor selection model for family farmers within the Pelotas city region, in the state of Rio Grande do Sul.

\section{MATERIAL AND METHODS}

Considering the multiplicity of intervening criteria in this decision making process, the use of a model as a support tool, which widely takes all factors into consideration, is built according to the population's interest becomes essential.

For this purpose, we have chosen the Multicriteria Method to support the decision (Multicriteria Decision Aid - MCDA) to perform this research. One of the main intentions of MCDA is to clarify the decision maker's behaviors during the process, offering them reflective arguments that enable them to shape and validate their own values within an interactive and constructivist process (GOMES, 2001).

This method was divided into three main stages: structuring, evaluation and recommendations. Each stage's procedures follow steps indicated by ENSSLIN et al. (2010) and have been successfully used in several researches focused on the primary sector (GOMES, 2001; XAVIER, 2010).

Structuring has focus on identifying stakeholders (Decision-makers, Facititator and other Stakeholders), defining decision-making process context and creating a tool (model) recognized by stakeholders as capable to articulate various aspects (Fundamentals Points of View - FPVs and Elementary Points of View - EPVs) necessary to solve the problem (ENSSLIN et al., 2010). The technique used for the structuring stage was a mean-end relations map (GOMES et al., 2010) in combination with the Value Focused Thinking Approach (KEENEY, 1992).

A mean-end relations map is a set of concepts related by influence links. It organizes values that are considered more important for decision-makers. The map connects concepts among themselves as a network of values and ideas, which are means for both the decision and the objectives to reach. A concept represents an aspect or relevant idea to the decision-making situation that stakeholders face, while its linkage comes out when they make the question, "Why is this concept important?" the answer generates another concept that is an end for the previous one. When the facilitator asks, "How can I get this concept?" the answer will generate a new idea that is the means of the previous one. For example, take the concept "to reduce producer fatigue": the question "Why is it important to reduce producer fatigue?" has generated the reply "to facilitate his/ her labor", i.e., this new concept is an END for the first one. Still referring to the first concept, the question "how can we reduce producer fatigue?" results as a reply "have an ergonomic machine", so this is another concept that is a MEAN for first one. The mean-end relation becomes: "have an ergonomic tractor" is a mean "to reduce fatigue" that "facilitates labor". Thus, under a systematic questioning sequence, a mean-end map could be built. Using this method, the decisionmaker's values are taken into account instead of working with alternatives. KEENEY (1992) states that focusing on alternatives might narrow decision-makers' minds and lead them to not clearly determine the issue they are facing.

During evaluation, the intention of the stage is to get the model workable, that is, to make it capable of assessing a varied set of actions to solve the problem. Making it workable consists of mathematically inserting the decision-maker's preferences to elaborate an ordering process of consistent actions with their values. For this, it is necessary to attribute a local value for each FVP through the Direct Rating method (ALFARES \& DUFFUAA, 2008). This technique is presented with more detail through the attribute for EPV 3.1 in the current work results. When the FVPs are turned into criteria, a weight is attributed to each one by the Swing Weights method (MUSTAJOKI et al., 2005). The technique is also presented in the results with more details. Each action's final evaluation (Global Value) is carried out through an additive aggregation model (CHOO and WEDLEY, 2008). Equation 1 can generically express the model: 


$$
G V(.)=\sum_{i=1}^{n} w_{i} \cdot v_{i}(.)
$$

where,

$G V($.$) is any action Global Value;$

$w_{i}$ is the criterion weight $i$;

$v_{i}($.$) is the local value of any action, due to criterion i$;

All model organization as well as required calculations were performed through spreadsheet.

Finally, in the recommendation stage, the generated model is put into operation; evaluating and creating possible action orders. It is important to highlight that within the Decision Aid paradigm any model, either multicriterial or not, must not be seen as external to the stakeholders' reality. On the contrary, it must be considered a tool built under their perceptions of decisionmaking context elements. It does not aim to describe real facts, but to work as a useful tool to generate and organize knowledge, providing communication among stakeholders related to the decision situation. (ROY, 2005).

The target population affected by this model was a group of 30 farmers from cities of Pelotas, Morro Redondo and Turuçu, cities from the state of Rio Grande do Sul, Southern Brazil. These cities had been chosen because they have a great concentration of family-based agricultural units which recently had acquired new tractors using PRONAF financial resources.

\section{RESULTS AND DISCUSSION}

The structuring stage has started with the definition of a team capable to represent the values and preferences of the regional farmers properly. Decision-makers were two college professors/ researchers with over twenty years of experience in agricultural machines, an agricultural engineer and agronomist that, beside his agricultural machine experience, works with smallholder farmers for more than ten years; finally, a fifth year undergraduate student of agricultural engineering course and a regional smallholder farmer's son were also involved. The Facilitator was a college professor and researcher with Doctorate in Decision-Aid Modeling and 10-year experience on this method application.

A cognitive map and a hierarchical structure of BPV/ EPV were built by the decision-makers from the following label: "a tractor purchase that promotes the family farmers' satisfaction in the studied region". To finish the model attributes (measuring scales), value functions and weights were defined to each BPV/EPV, turning them into criteria.

For example: see the attribute of the criterion 3.1, Access to maintenance items (Figure 1). This criterion arose with the periodical tractor maintenance the farmers have been performing by themselves. Thus, it was identified that there is a need to remove hoods, fairings and other parts to expose the items to be maintained. Periodical maintenance items (daily, weekly and monthly) set out in machine operation manuals have been considered for this research. Decision-makers have verified that access depends on fixing type (fast-coupling; wingnut; tool needs) and on how to access maintenance items (direct and indirect access). The combination of these possibilities generated the above attribute. A value function associated with it was generated through the Direct Rating technique. It sets value 0 (zero) as the worst and 100 (one hundred) as the best attribute level; it means that rising up from the lowest to the highest level produces a 100-point difference in preference. Then, the decision-maker is questioned to compare this increase (from the worst to the best level) with the increase from the worst level to intermediate levels, choosing a score number for this comparison. This procedure was similar for all attributes and allowed them to work simultaneously with qualitative and quantitative measuring scales. It also allowed the aggregation process to be done as described in equation 1 . 


\begin{tabular}{|l|l|c|}
\hline $\begin{array}{c}\text { Level of } \\
\text { Impact }\end{array}$ & \multicolumn{1}{|c|}{ Description } & $\begin{array}{c}\text { Local value } \\
\text { function } \\
\left(v_{3.1}\right)\end{array}$ \\
\hline N6 & Maintenance items with fast-coupling and direct access & 100 \\
\hline N5 (Good) & Maintenance items with wingnut and direct access & 80 \\
\hline N4 & Maintenance items that need tools and direct access & 35 \\
\hline N3 (Neutral) & Maintenance items with fast-coupling and indirect access & 15 \\
\hline N2 & Maintenance items with wingnut and indirect access & 10 \\
\hline N1 & Maintenance items that need tools and indirect access & 0 \\
\hline
\end{tabular}

FIGURE 1. Attribute for the criterion 3.1 with Neutral and Good levels and its value function.

The attribute of the criterion 3.2 Technical assistance near/ fast (Figure 2) does not present intermediate levels and the value function assumes only 0 and 100 scores for the worst and best levels, respectively. In this in case, we considered that manufacturer technical assistance would be considered near when it locates at less than $50 \mathrm{~km}$ from the studied district and that it would be considered fast if consumer service was carried out within 48 hours of the call.

\begin{tabular}{|l|l|c|}
\hline $\begin{array}{c}\text { Level of } \\
\text { Impact }\end{array}$ & \multicolumn{1}{|c|}{ Description } & $\begin{array}{c}\text { Local value } \\
\text { function } \\
\left(v_{3.2}\right)\end{array}$ \\
\hline N2 (Good) & Yes, there is technical assistance near and fast & 100 \\
\hline N1 (Neutral) & No, there is no technical assistance near and fast & 0 \\
\hline
\end{tabular}

FIGURE 2. Attribute for the criterion 3.2 with Neutral and Good levels and its value function.

The Neutral and Good levels for attributes are important to determine weights of each criterion. These levels are defined to avoid using the outermost values of the scale, which might typically consist in high repulsion or attractiveness points. As the aggregation model is additive, it is necessary to assure weight stability, i.e., weights must be constant for the whole scale. In other words, the criteria weights cannot depend on the attribute impact level.

For weights determination to each criterion, we used Swing Weights method. For example, for criterion 3.1 and criterion 3.2, decision-makers were asked to consider (hypothetically) a tractor that could impact at Neutral level for both criteria. Then, it was questioned which criterion they would choose to pass from Neutral level to Good one in first place? Decision-makers have chosen criterion 3.2 and, to this jump (Swing), it was attributed 100 points (gross weight of criterion 3.2); second jump would correspond to criterion 3.1 and they had understood that, comparatively, this jump (Swing) would represent 80 points (gross weight of criterion 3.1). Weights are obtained normalizing the values, thus, $w_{3.1}=0.45$ and $w_{3.2}=0.55$.

Attributes and value functions were done for all BPV/ EPV, as well as weight determination. Hence, it was possible to observe the impact of tractors within each attribute, represented by its value function. In Table 1 are presented all criteria and their respective attributes, weights and also the value function scores of tractors that were bought by the farmers. The scores were based on data from machine operation manuals and determination from proper tractors (turning radius, seat comfortable positions, noise level, sharp edges and safety alert symbols), followed by testing standards when needed. The Attribute of Operational cost was determined by means of required lubricant and spare part price reporting to periodic maintenance according to operator manual description and estimates of fuel consumption by farmers. Each tractor price is to be used for the Acquisition Cost, attribute which is supplied by the dealer. However, in this case the value scale is inverted. Therefore, it was allocated 100 points for a minimum price (desirable); and zero for a maximum (undesirable); and for other prices were attributed values in accordance with Direct Rating technique. 
TABLE 1. Hierarchical structure of criteria with respective weights from decision-maker group that represented regional farmers; attribute scale unit and score in value function of assessed tractors.

\begin{tabular}{|c|c|c|c|c|c|c|}
\hline \multirow[t]{2}{*}{ Criterion } & \multirow{2}{*}{$\begin{array}{l}\text { Weight } \\
\left(w_{i}\right)\end{array}$} & \multirow{2}{*}{$\begin{array}{c}\text { Atribute } \\
\text { (Measuring scale) }\end{array}$} & \multicolumn{4}{|c|}{$\begin{array}{l}\text { Local value function of assessed } \\
\text { tractors }\left(v_{i}(.)\right)^{* *}\end{array}$} \\
\hline & & & {$[[a]]$} & $b$ & $c$ & $d$ \\
\hline $\begin{array}{l}\text { 1. OPERATIONAL COST } \\
\text { 1.1 Diesel consumption } \\
\text { 1.2 Maintenance (excluding tyres) }\end{array}$ & $\begin{array}{l}0.20 \\
0.63 \\
0.37\end{array}$ & $\begin{array}{l}L h^{-1} \\
R \$ h^{-1}\end{array}$ & $\begin{array}{l}100 \\
72.7\end{array}$ & $\begin{array}{l}100 \\
72.4\end{array}$ & $\begin{array}{c}85 \\
71.8\end{array}$ & $\begin{array}{c}70 \\
59.6\end{array}$ \\
\hline 2 ACQUISITION COST & 0.22 & $\mathrm{R} \$$ & 100 & 87 & 50.3 & 28.3 \\
\hline $\begin{array}{l}\text { 3. EASE OF MAINTENANCE } \\
\text { 3.1 Access to maintenance item } \\
\text { 3.2 Technical assistance near/ fast }\end{array}$ & $\begin{array}{l}0.10 \\
0.45 \\
0.55\end{array}$ & $\begin{array}{l}\text { (built) } \\
\text { (yes/ no) }\end{array}$ & $\begin{array}{l}100 \\
100\end{array}$ & $\begin{array}{l}100 \\
100\end{array}$ & $\begin{array}{l}100 \\
100\end{array}$ & $\begin{array}{l}100 \\
100\end{array}$ \\
\hline $\begin{array}{l}\text { 4. CAPACITY OF TRACTOR } \\
\text { 4.1 Traction capacity } \\
\text { 4.1.1 Engine capacity } \\
\text { 4.1.2 Assisted front wheel drive } \\
\text { 4.1.3 Gears between } 4 \text { and } 10 \mathrm{~km} / \mathrm{h} \\
\text { 4.2 Operational capacity } \\
\text { 4.2.1 Torque reserve } \\
\text { 4.2.2 Fuel autonomy } \\
\text { 4.2.3 Independent PTO activation } \\
\text { 4.2.4 Remote-control valves } \\
\text { 4.2.5 Turning radius } \\
\text { 4.2.6 Tractor width } \\
\text { 4.2.7 Lifting capacity }\end{array}$ & $\begin{array}{l}0.26 \\
0.46 \\
0.24 \\
0.36 \\
0.40 \\
0.54 \\
0.15 \\
0.04 \\
0.20 \\
0.07 \\
0.23 \\
0.22 \\
0.09\end{array}$ & $\begin{array}{c}\mathrm{kW} \\
\text { (yes/ no) } \\
\text { Number of gears } \\
\text { \% torque reserve } \\
\mathrm{h} \\
\text { (yes/ no) } \\
\text { Number of valves } \\
\mathrm{m} \\
\mathrm{m} \\
\mathrm{kgf}\end{array}$ & $\begin{array}{c}0 \\
100 \\
0 \\
40 \\
\\
100 \\
100 \\
80 \\
94.1 \\
94.2 \\
0\end{array}$ & $\begin{array}{c}36 \\
100 \\
0 \\
40 \\
\\
0 \\
100 \\
100 \\
88.2 \\
82.7 \\
0\end{array}$ & $\begin{array}{c}46.8 \\
100 \\
85 \\
40 \\
100 \\
100 \\
100 \\
52.9 \\
51.7 \\
0\end{array}$ & $\begin{array}{c}61.7 \\
100 \\
85 \\
\\
40 \\
\\
0 \\
100 \\
100 \\
29.4 \\
28.6 \\
0\end{array}$ \\
\hline $\begin{array}{l}\text { 5. ERGONOMICS } \\
\text { 5.1 Exhaust pipe position } \\
\text { 5.2 Thermal and acoustic isolation } \\
\text { 5.3 Seat comfort positions } \\
\text { 5.4 Noise level } \\
\text { 5.5 Dust/ air deflector } \\
\text { 5.6 Gear stick position } \\
\text { EPV 5.7 Steering wheel inclination }\end{array}$ & $\begin{array}{l}0.14 \\
0.23 \\
0.15 \\
0.17 \\
0.22\end{array}$ & \begin{tabular}{|} 
Qualitative \\
(yes/ no) \\
Number of \\
positions \\
h without earpiece \\
protector \\
(yes/ no) \\
(lateral/ central) \\
(yes/ no)
\end{tabular} & $\begin{array}{c}100 \\
0 \\
25 \\
0\end{array}$ & $\begin{array}{c}0 \\
0 \\
75 \\
0\end{array}$ & $\begin{array}{c}100 \\
0 \\
75 \\
0 \\
\\
0 \\
0 \\
0\end{array}$ & $\begin{array}{c}100 \\
0 \\
75 \\
0 \\
\\
100 \\
0 \\
0\end{array}$ \\
\hline $\begin{array}{l}\text { 6. SAFETY } \\
\text { 6.1 ROPS presence } \\
\text { 6.2 Synchronized gearshift } \\
\text { 6.3 Tail light } \\
\text { 6.4 Main PTO shield } \\
\text { 6.5 Sharp edge presence } \\
\text { 6.6 Safety alerts }\end{array}$ & $\begin{array}{l}0.08 \\
0.25 \\
0.18 \\
0.06 \\
0.22 \\
0.11 \\
0.18\end{array}$ & \begin{tabular}{|c|} 
Qualitative \\
(yes/no) \\
(presence/ \\
absence) \\
(presence/ \\
absence) \\
\% sharp edges \\
\% existing alerts
\end{tabular} & $\begin{array}{c}20 \\
0 \\
100 \\
100 \\
100 \\
0\end{array}$ & $\begin{array}{c}20 \\
0 \\
100 \\
100 \\
100 \\
0\end{array}$ & $\begin{array}{c}20 \\
0 \\
100 \\
100 \\
100 \\
0\end{array}$ & $\begin{array}{c}20 \\
0 \\
100 \\
100 \\
100 \\
0\end{array}$ \\
\hline
\end{tabular}

* Roll over protection structure ** Scoring representation (dimensionless) of physical describer.

Through the results presented in Table 1, it is readily verified that many traditionally adopted items in the cost analysis of tractor use are not present. This might be explained by the fact that the multicriteria method aims to show the way farmers take their decisions. During the mean-end map design, the items perceived as costs by farmers were purchase price, fuel consumption (hourly cost of diesel) and maintenance cost. This same trend of non-adopting classic parameters of decision making is verified in criteria Tractor capacity, Safety and Ergonomics, which does not imply in model error, but rather a proper way to model the way they choose.

In the same way, operational tractor implement capacity is not present in the model, making 
the target area to be worked with a determinant for tractor choice, as used by authors such as SØGAARD \& SØRENSEN (2004). Analyzing this situation, together with the area of the current farmers (of which $80 \%$ produce on areas of up to 20ha), it was verified that virtually any four-wheel tractor and its implement would have enough operational capacity for the work. Thus, area became secondary in the model.

Another aspect of the Decision Aid model generated by the multicriteria method is that it is a simplification of the language used in attributes. This can be seen in criterion 4.1 Engine capacity in Table 1. Generic description, which is easily understood by farmers, was preferred instead of a technical one, which could be rated power in $\mathrm{kW}$ with testing standard specification.

Another highlighted point from Table 1 is that attributes for Tractor capacity may extend beyond haul capacity of a particular equipment, which is generally used to measure/dimension tractors as in the model proposed by MEHTA et. alii (2011) for smallholder farmers. Presented items include determinant aspects for tractor operation success in these small farms, since they show the dynamic performance that power sources must have, saving the farmer's time, who is the only available labor force for the most part of the year.

Criterion 4.2.7 Lifting capacity of the three-point coupling system was incorporated, although assessed tractors present same score for this criterion. However, it was verified that there are lower power tractors, which would not be able to raise available equipment for some of the assessed rural enterprises, expressing farmers' concern.

Both criteria weights related to maintenance (access to maintenance items $-w_{3.1}=0.45$ and technical assistance $-w_{3.2}=0.55$ ) and those related to tractor capacity (traction capacity $-w_{4.1}=0.46$ and operation capacity $-w_{4.2}=0.54$ ) revealed themselves balanced in the model, which showed a similar capacity to contribute to the satisfaction with the chosen tractor.

With respect to wheel drive capacity, the model gives more value to a higher number of gears between 4 and $10 \mathrm{~km} \mathrm{~h}^{-1}\left(w_{4.1 .3}=0.40\right)$ and assisted front wheel drive presence $\left(w_{4.1 .2}=0.36\right)$ than the engine power $\left(w_{4.1 .1}=0.24\right)$, showing that it prioritizes tractor effectiveness to adjust to work conditions and to transform engine power into useful wheel drive power.

Among listed items in criterion 4.2 Operation capacity turning radius, tractor width and PTO independent activation obtained the biggest weights: $0.23,0.22$ and 0.20 respectively. These are essential and important traits for tractor use in fruit-growing operations, the main activity in 51.4\% of evaluated rural properties, since they facilitate tractor-implement maneuver between tree rows.

In criterion 5. Ergonomics there was great difficulty to express farmers' needs and desires that were used as decision elements of the attributes for the model, as there was no clear perception about comfort. It can be observed that for farmers' first tractor purchase, the machine itself represents a great benefit with regard to life quality and comfort improvement. Thus, decisionmakers and facilitator defined criteria that would describe desired ergonomics level for farmers. Same procedure was used for criterion 6. Safety.

Observing Table 1, we can note the absence of hydraulic steering wheel, that was supposed to offer comfort during operation. This was seen in all purchased tractors by studied farmers, being a standard item for $100 \%$ tractors up to $55 \mathrm{~kW}$. Therefore, it would not make any difference to either of the evaluated tractors.

A time unit was used to express noise level as it is related to daily exposition limits of continuous and intermittent noises settled by standard (NR-15 - Unhealthy activities and operations). According to the decision-makers' understanding, that indirect measure seemed to make more sense for farmers than using a decibel scale (dB).

The most valued items in criterion 5. Ergonomics were exhaust pipe location, noise level and seat quality. When it comes to the exhaust pipe, the purchased tractors should not release engine gases toward their operator, avoiding discomfort and future health problems. Additionally, the large 
number of seat adjustment possibilities make it so that it can be optimized for each person, reducing fatigue as well.

The best valued items within criterion 6. Safety (Table 1) were ROPS (Rollover Protection Structure) presence $\left(w_{6.1}=0.25\right)$; PTO main shield presence $\left(w_{6.4}=0.22\right)$ and synchronized gearbox $\left(w_{6.2}=0.18\right)$. Due to the kind of work the soon-to-be acquired tractors will be used for, such as driving within inter-rows peach orchards, folded ROPS are essential. In this setup, the tractor will be used without obstacles in orchards (folded ROPS) and other agricultural operations (ROPS in protection position). It is worth noting that this is not the ideal situation, because it leaves the operator unprotected half of the time. Even so, there is no other option in Brazilian-made tractors. Therefore, evaluated tractors have not been differentiated for this characteristic; other tractors will have differing points at these aspects.

Having the decision aiding model built with every criteria valued and weighed, Table 2 allows observing how all of the 30 family-purchased tractors impact on them and calculates their respective Global Value. Each tractor was evaluated throughout every model criteria to identify the most adequate one. The acquired tractors are four different models of same manufacturer. All of them presented hydraulic steering wheel, assisted front wheel drive, two PTO rotation speeds, ROPS and cover. Table 2 presents the main tractor characteristics.

TABLE 2. Summarized tractor technical specifications.

\begin{tabular}{ccccccc}
\hline Tractor & $\begin{array}{c}\text { Engine power } \\
(\mathrm{kW})\end{array}$ & Mass & $\begin{array}{c}\text { Hydraulic lifter } \\
\text { capacity } \\
(\mathrm{kg})\end{array}$ & $\begin{array}{c}\text { Gears } \\
\text { forward } \\
(\text { number })\end{array}$ & $\begin{array}{c}\text { Length } \\
(\mathrm{mm})\end{array}$ & Width \\
\hline$a$ & 14.7 & 1,310 & 450 & 12 & 2,675 & 1,235 \\
$b$ & 18.4 & 1,430 & 500 & 12 & 2,900 & 1,290 \\
$c$ & 25.7 & 1,780 & 780 & 8 & 3,230 & 1,450 \\
$d$ & 33.1 & 2,116 & 1,000 & 16 & 3,825 & 1,625 \\
\hline
\end{tabular}

Model scores range between 0 and 100 and express the Global Value of these tractors. These Global Value scores are compared with the most purchased models. By these results, supposingly, the model could be lined up with decisions intuitively taken by those families. For example, Equation 2 calculated the Global Value of the tractor a $(14.7 \mathrm{~kW})$.

$$
G V(a)=w_{1} *\left(w_{1.1} * v_{1.1}(a)+w_{1.2} * v_{1.2}(a)\right)+\ldots+w_{6} *\left(w_{6.1} * v_{6.1}(a)+\ldots+w_{6.6} * v_{6.6}(a)\right)
$$

This procedure was carried out for all other tractors and its result is summarized in Table 3, which still presents an empirical verification in 30 visited properties of producers that bought tractors using the More Foods Program.

TABLE 3. Global value calculated by multicriteria decision aiding model and number of purchased tractors by agriculturists from studied region.

\begin{tabular}{ccccc}
\hline Item & Tractor $a$ & Tractor $b$ & Tractor $c$ & Tractor $d$ \\
\hline Global value & 72.6 & 67.8 & 63.8 & 55.6 \\
Number of purchased tractors & 16 & 2 & 11 & 1 \\
\% purchased tractors & 53.3 & 6.7 & 36.7 & 3.3 \\
\hline
\end{tabular}

We have noted that Global Values of tractors $a$ and $d$ match with empirically observed data, that is, the best and worst evaluated tractors by the model (analytical result) coincide with purchasing decisions of farmers (intuitive results). However, for the intermediate power tractors, the model predicts a different outcome of that observed in farmers' acquisitions. Therefore, a more attentive and detailed analysis is necessary to understand what is behind these results. 
At first place, it is necessary to show how the proposed model captured the farmers decisionmaking dilemmas, what is shown through Global Value decomposition among all criteria (Table 4).

TABLE 4. Local value by criterion of evaluated tractors.

\begin{tabular}{lcrrrr}
\hline \multirow{2}{*}{ criterion } & \multirow{2}{*}{ Weight $\left(w_{i}\right)$} & \multicolumn{4}{c}{ Local Value $\left(v_{i}().\right)$} \\
\cline { 3 - 6 } & & & Tractor $a$ & Tractor $b$ & Tractor $c$ Tractor $d$ \\
\hline 1. OPERATIONAL COST & 0.20 & 89.9 & 89.8 & 80.1 & 66.2 \\
2. PURCHASE COST & 0.22 & 100.0 & 87.0 & 50.3 & 28.3 \\
3. EASE OF MAINTENANCE & 0.10 & 100.0 & 100.0 & 100.0 & 100.0 \\
4. TRACTOR CAPACITY & 0.26 & 58.7 & 59.1 & 70.1 & 63.9 \\
5. ERGONOMICS & 0.14 & 27.3 & 12.8 & 35.8 & 42.8 \\
6. SAFETY & 0.08 & 44.0 & 44.0 & 44.0 & 44.0 \\
\hline
\end{tabular}

One first analysis refers to criteria 3 and 6, whose performance was equal for all tractors. This comes from the previously mentioned fact that all evaluated tractors are different deriving models of one same manufacturer. Since this manufacturer implements the same maintenance and safety politics for all line models, these criteria have not contributed for Global Value differentiation. Nevertheless, except for criterion 3, whose scoring reached its maximum, criterion 6 shows to manufacturer opportunities to improve safety (check Table 1), because there are 56 points remaining to reach maximum value.

The most intriguing comparison is between $b$ and $c$ tractors. Tractor $b$ has better performance in criteria 1 and 2, which are related to costs, while tractor $c$ has better performance in criteria 4 and 5, which are related to tractor capacity and ergonomics. Together criteria 1 and 2 add up 42\% of Global Value, while criteria 4 and 5 adds 40\%. Although these percentages are close, the model shows that advantage obtained for tractor $c$ in criteria 4 and 5 are not compensated by the advantage obtained by tractor $b$ in criteria 1 and 2 .

Divergence with empirical data raises an obvious assumption. The model underestimated the weights of criteria 4 and 5 and/ or overestimated those of criteria 1, 2, 3 and 6. This suggests that the set of weights will need to be re-calibrated to achieve an improved adjustment between model results and empirical data. In other words, in a way similar to the econometric methods, the mathematical function that better fits to a set of data has to be always chosen; in this case, we must decide on a set of weights that allows better convergence between analytic results (Global Value scores) and intuitive ones (farmers' purchase decisions).

We verified that purchased tractors by the families are small $(96.7 \%$ with power under $25.7 \mathrm{~kW}$ and maintenance cost inferior to $\mathrm{R} \$ 1.04 \mathrm{~h}^{-1}$ ); with greater technological characteristics of operational capacity and versatility, however. Among these features, we might highlight assisted front wheel drive, PTO independent activation,two remote-control hydraulic valves (100\% of models) and four gears between 4 and $10 \mathrm{~km} \mathrm{~h}^{-1}$ (60.0\% of models).

The use of this methodology for machine selection is not quite common. Thus, it becomes difficult to contrast our results with other works. Furthermore, a major concern was to understand motivation in decision making by the farmers. AYBEK and BOZ (2006) studied the influence of several factors in tractor selection for small farmers in Turkey and grouped them into technical socioeconomic characteristics. In the first group, fuel consumption, power, availability of spare parts, maintenance services and PTO characteristics were considered very important. For the socioeconomic group, the characteristics considered more important were purchase cost, tractor brand, cabin, being a commonly used tractor. While comparing values observed by these authors with the current work, it is noted that item classifications diverge from each other: fuel consumption was considered by them as a technical aspect while taken as a cost in the present model. Some of the aspects, considered important by those authors, were highly valued by the current model as well, such as: purchase cost, fuel consumption, technical assistance, engine capacity and PTO 
independent activation.

When results are analyzed in a decision aiding perspective, we conclude that both the decision-makers' and facilitator's work were properly done, once they identified and mapped the majority of the farmer needs, desires, restrictions and yet $53.3 \%$ of them had acquired a tractor that got the biggest score. One fact that has contributed for this was the homogeneity of sampled properties especially for important aspects as area (56.7\% between 10 and 30 ha), main crop (51.4\% peach cultivation) and annual gross income ( $73.3 \%$ between $\mathrm{R} \$ 30,000$ and $\mathrm{R} \$ 90,000)$. This observation allows inferring on the method effectiveness in selecting tractors for smallholder farmers and encouraging subsequent studies on this issue, once knowledge was obtained for this farmer group, aiming to use it on a large scale of properties with a prescriptive approach.

\section{CONCLUSIONS}

The main objective of this work was to create a model to evaluate tractors in order to include farmers' values and complexity. In that sense, we consider the research to have reached its goal. The model has incorporated the farmer's point of view for both criteria identification and weight determinations. Mixing technical criteria with other criteria considered important by farmers is also determinant during purchase decision. This model shows the possibility of mixing farmers' technical and managerial criteria.

However, the generated model is not supposed to generalize the evaluation for all types of farmers from all states and cities. The proposal has the characteristic of a case study and contemplates producers from Pelotas and neighborhood cities, in Sothern Brazil. For this purpose, it has certain emphasis in the methodology and result descriptions. Thus, we see the model as a starting point so that other models could be developed and adapted to different regions or situations.

Nonetheless, the use of the current model to evaluate tractors for other farmer groups may be indicated, in case it is possible to outline a parallel between our criteria set, weights and value functions and those of the other farmer groups.

\section{REFERENCES}

ANFAVEA Associação Nacional dos Fabricantes de Veículos Automotores. Máquinas agrícolas automotrizes - produção em “ano”. 2011. Disponível em <www.anfavea.com.br/tabelas2010.html>. Acesso em: jun. 2011.

ALFARES, H. K.; DUFFUAA, S. O. Assigning cardinal weights in multi-criteria decision making based on ordinal ranking. Journal of Multi-Criteria Decision Analysis, v.15, n.5-6, p.125-33, 2008.

ANDERSSON, N. L. M. MACHADO, A. L. T. REIS, A. V. MACHADO, R. L. T. MEDEIROS, F. A. TROGER, H. C. H. TEIXEIRA, S. S. MORAIS, C. S. Características das unidades familiares de produção que adquiriram tratores, através do PRONAF, na região da Santa Áurea - Pelotas/RS. In: ENCONTRO DA PÓS-GRADUAÇÃO, 11. 2009, Pelotas. Anais...Pelotas: UFPel, 2009. 1 CDROM.

AYBEK, A.; BOZ, I. The influence of various factors on tractor selection. Agricultural Mechanization in Asia, Africa, and Latin America, Tokyo, v.37, n.2, p.58-61, 2006.

CHOO, E. U.; WEDLEY, W. C. Comparing fundamentals of additive and multiplicative aggregation in ratio scale multi-criteria decision making. The Open Operational Research Journal, v.2, p.1-7, 2008.

ENSSLIN, L.; GIFFHORN, E.; ENSSLIN, S. R.; PETRI, S. M.; VIANNA, W. B Avaliação de desempenho de empresas terceirizadas com o uso da metodologia multicritério de apoio à decisão construtivista. Pesquisa Operacional, Rio de Janeiro, v.30, n.1, p. 125-152, 2010.

GOMES, L. F. A. M.; RANGEL, L. A. D.; JERÔNIMO, R. L. A study of professional mobility in a large corporation through cognitive mapping. Pesquisa Operacional, Rio de Janeiro, v.30, n.2, 
p.331-44. 2010.

GOMES, M. C. Apoio à decisão em empresas familiares em processo de evolução - um modelo multicritério em um estudo de caso na indústria de conservas de Pelotas/RS. 2001. 423f. Tese (Doutorado em Engenharia de Produção) - Departamento de Engenharia de Podrução, Universidade Federal de Santa Catarina, Florianópolis, 2001.

GUILHOTO, J. J. M.; AZZONI, C. R.; SILVEIRA, F. G.; ICHIHARA, S. M.; DINIZ, B. P. C.; MOREIRA, G. R. C. PIB da Agricultura Familiar : Brasil-Estados. Brasília: MDA, 2007. 172 p. (Estudos, 19).

KEENEY, R. L. Value focused thinking: a path to creative decision making. Cambridge; Harvard University Press, 1992.

MACHADO, A. L. T.; REIS, A. V.; MACHADO, R. L. T. Tratores para a agricultura familiar: guia de referência. Pelotas: Ed. Universitária UFPEL, 2010. 124 p.

MAWAKDIYE, A. Porteira aberta para os tratores. Problemas Brasileiros, n.398, 2010.

MDA. Ministério de Desenvolvimento Agrário. Programa mais Alimentos - produção primária. Disponível em <http://www.mda.gov.br/portal/saf/maisalimentos/>. Acesso em: maio 2011.

MEHTA, C.R; SINGH, K.; SELVAN, M.M. A decision support system for selection of tractorimplement system used on Indian farms. Journal of Terramechanics, Oxford, v.48, p.65-73. 2011.

MUSTAJOKI, J.; HÄMÄLÄINEN, R. P.; SALO, A. Decision support by interval SMART/SWING - incorporating imprecision in the SMART and SWING methods. Decision Sciences, Atlanta, v.36, n.2, p.317-39. 2005.

ROY, B. Paradigms and challenges. In: FIGUEIRA, J.; GRECO, S.; EHROGOTT, M. Multiple criteria decision analysis: state of the art surveys. Boston: Springer-Science, 2005.

SØGAARD, H. T.; SØRENSEN, C. G. A model for optimal selection of machinery sizes within the farm machinery system. Biosystems Engineering, London, v.89, n.1, p.13-28. 2004.

XAVIER, J. H. V. Avaliação de sistemas de cultivo de milho grão sequeiro no contexto da agricultura familiar: uma aplicação da metodologia multicritério de apoio à decisão (MCDA). 2010. 321f. Tese (Doutorado em Sistemas de Produção Agrícola Familiar), Faculdade de Agronomia Eliseu Maciel, Universidade Federal de Pelotas, Pelotas, 2010. 